\title{
Effect of Storage Containers on Quality of Household Drinking Water in Urban Communities in Ibadan, Nigeria
}

\author{
Olanrewaju Onigbogi ${ }^{1}$, Oluwatoyin Ogunyemi ${ }^{2}$ \\ ${ }^{1}$ Department of Community Health and Primary Care, University of Lagos, Lagos, Nigeria \\ ${ }^{2}$ Department of Environmental Health, School of Hygeine, Ijero Ekiti, Ekiti State, Nigeria
}

\begin{tabular}{l} 
Article Info \\
\hline Article history: \\
Received Sept 1, 2014 \\
Revised Oct 20, 2014 \\
Accepted Nov 16, 2014 \\
\hline
\end{tabular}

Keyword:

Containers

Quality

Storage

Water

\begin{abstract}
The method of storage is essential in maintaining water purity and safety for drinking purposes. This study assessed the effect of various storage containers on household drinking water quality in a resource-limited setting. A quasi-experimental design was adopted. Four communities using protected springs as household drinking water sources were purposively selected. Forty-four households were selected and randomly assigned to four treatment groups; namely Covered Buckets with Taps (CBT), Covered Buckets without Tap (CB), Covered Kegs with Taps (CKT) and Covered Kegs without Tap (CK). Physicochemical analysis and bacteriological analysis were carried out on the water samples before and after they were put in the containers. Data was analyzed using SPSS version 12 . At baseline, mean $\mathrm{pH}$ values of water samples from the springs and RSC were $6.4 \pm 0.6$ and $7.1 \pm 0.7$ respectively which were above the recommended. Mean chloride concentration of springs $(14.3 \pm 7.4 \mathrm{mg} / \mathrm{l})$ and RSC $(19.3 \pm 10.0 \mathrm{mg} / \mathrm{l})$ samples were below recommended. Mean Total Coliform Count (TCC) of the springs in the four communities was $18.0 \pm 4.0$ and mean TCC of RSC was 12.7 \pm 4.9 . Five percent of water samples from RSC had mean E.coli count of $100 / 100 \mathrm{ml}$. The mean TCC after introducing CB, CBT, CK and CKT in all the communities were $10.0 \pm 4.0,8.5 \pm 4.2,6.9 \pm 2.8$ and $7.3 \pm 3.7$ respectively $(\mathrm{p}<0.05)$. The use of covered kegs without tap was best in reducing contaminants in drinking water. Education on appropriate household drinking water storage and handling practices is recommended.
\end{abstract}

Copyright (C) 2014 Institute of Advanced Engineering and Science. All rights reserved.

\section{Corresponding Author:}

Olanrewaju Onigbogi,

Department of Community Health and Primary Care,

University of Lagos, Lagos, Nigeria

Telephone: 08074233789.

Email: oonigbogi@unilag.edu.ng

\section{INTRODUCTION}

Access to safe drinking water has improved steadily and substantially over the last decades in almost every part of the world. It is estimated that by 2025 more than half of the population of the world will have some water-based vulnerability [1]. A report by the Federal Office of Statistics estimates that out of the total urban household in Nigeria, only $53.3 \%$ had access to pipe-borne water while $43.3 \%$ of the household in Southwest Nigeria (of which Ibadan is part) had such access [2]. In 2010 about 85\% of the global population (6.74 billion people) had access to piped water supply through house connections, protected springs and protected wells. However, about 14\% (884 million people) did not have access to an improved water source and had to use unprotected wells or springs, canals, lakes or rivers for their water needs [2].

Some of the dangers associated with water can be direct or indirect contamination which could be as a result of excrement of warm blooded animals. Water related disease is one of the major health problems 
globally that has estimated four billion cases of diarrhoea annually representing $5.7 \%$ of the global disease burden in the year 2000 [3]. Safe water storage is the use of clean containers with covers and good hygiene behaviours that prevent contamination during water collection, transport, and storage in the home [2]. Higher levels of microbial contamination and increased microbial quality are associated with storage vessels having wide openings (e.g., buckets and pots), vulnerability to introduction of hands, cups and dippers that can carry faecal matter, and lack of a narrow opening for dispensing water [2].

Studies have shown that sizes of containers opening plays significant role in maintaining water quality, but not so much had been said on how the different opening sizes of container had affected water purity/quality [4],[5].

\section{RESEARCH METHOD}

\section{Study Area}

Ibadan is the largest indigenous urban centre in Sub-Sahara Africa with a projected population of four million. It is characterized by an elevation of $210 \mathrm{~m}$ above the sea level with isolated ridges and peaks rising to an elevation of $274 \mathrm{~m}$. The study was carried out in four different communities in Ibadan North Local Government Area.

\section{Study Design}

A quasi-experimental design was adopted for the study. It involved quantitative method (laboratorybased assessment from spring sources to household storage containers).

\section{Sampling Procedure}

Four communities in the Ibadan North Local Government that used spring as their sole source of drinking water were purposively selected. In the communities a two stage sampling procedure was adopted. A list of enumeration areas in the selected communities was obtained from the National Population Commission. From the enumeration areas, one enumeration area was randomly selected. The households in the enumeration areas were numbered and the desired numbers of respondents were selected using systematic random sampling method.

\section{Laboratory Analysis (physico-chemical and Bacteriological analysis of water samples)}

The environmental field sampling that was carried out in this study was collection of water samples from the source of water supply (springs), household regular storage containers and introduced containers for determination of physico-chemical and bacteriological quality.

\section{Sample Collection for physico-chemical analysis}

Water samples were collected according to recommended standard methods described by the American Public Health Association [6]. Plastic kegs of 2 liter capacity were used to collect samples for physicochemical parameters while plastic dispense bottles of $60 \mathrm{mls}$ capacity were used to collect samples for heavy metal analysis. The samples were collected from the taps of the springs and also with the aid of a cup from their regular storage containers for physico-chemical analysis. Samples were immediately placed in a lightproof insulated box containing melting ice with water to ensure rapid cooling and the analysis were commenced immediately the samples got to the laboratory. Some of the parameters analysed included $\mathrm{pH}$, conductivity, total dissolved solids, alkalinity, chloride, total hardness total solids, iron, manganese and lead.

\section{Sample collection for bacteriological analysis}

The containers that were used for sample collection were properly washed, rinsed with distilled water, dry and sterilized in an oven at temperature of $170^{\circ} \mathrm{C}$ for 1 hour. All the containers were closed until the point of sample collection. Samples were collected from springs, regular storage containers, covered buckets with and without taps and covered kegs with and without taps. After the sample collection, the containers were closed immediately and taken to the laboratory for analysis. Samples were collected under aseptic condition. 


\section{Data Analysis}

All the data collected was analyzed using SPSS (Statistical Package for the Social Sciences). The analysis included descriptive statistics such as means. Also, inferential statistics such as chi-square test, t-test and ANOVA at 5\% level of significance were also used to analyze data.

\section{Ethical consideration}

The recruitment of respondents was based strictly on informed consent. The aims and objective of the study was fully explained to the participants. The study participants were also assured of the confidentiality of the information supplied.

\section{RESULTS AND DISCUSSION}

This section presents the results of water analysis from all the communities studied. Water samples from sources (spring), Household regular storage containers and the four different treatment containers introduced- Covered buckets with taps, Covered buckets without taps, Covered kegs with taps and Covered kegs without taps were collected and analyzed for physico-chemical and bacteriological quality parameters. The results were compared with World Health Organization (WHO) guidelines and standard for drinking water quality by Standard Organisation (SON) of Nigeria.

Table 1. Physico-chemical analysis of water samples in all the communities

\begin{tabular}{ll}
\hline \multicolumn{1}{c}{ Parameter } & \multicolumn{1}{c}{ Value } \\
\hline $\mathrm{pH}$ & $7.09 \pm 0.65$ \\
Mean Total Solid & $1509.00 \pm 221.68$ \\
Mean Conductivity & $365.75 \pm 184.14$ \\
Mean Total Hardness & $64.88 \pm 15.03$ \\
Mean Alkalinity $(\mathrm{mg} / \mathrm{L})$ & $1.85 \pm 0.98$ \\
Mean Chloride $(\mathrm{mg} / \mathrm{L})$ & $19.28 \pm 9.18$ \\
Iron $(\mu \mathrm{g} / \mathrm{ml})$ & $0.16 \pm 0.07$ \\
Lead $(\mu \mathrm{g} / \mathrm{ml})$ & $0.02 \pm 0.01$ \\
Manganese $(\mu \mathrm{g} / \mathrm{ml})$ & $0.01 \pm 0.01$ \\
\hline
\end{tabular}

Table 1 above outlines the Physico-chemical analysis of water samples in all the communities. The water samples had a mean $\mathrm{pH}$ value of 7.09 \pm 0.65 which falls within the range of WHO guideline of 6.5-8.5. The mean total solid was $1509.00 \pm 221.68 \mathrm{mg} / \mathrm{l}$ and the mean total dissolved solid was $196.00 \pm 107.27 \mathrm{mg} / \mathrm{l}$. These were also within the $500 \mathrm{mg} / \mathrm{l}$ of the WHO guideline limits. The mean conductivity of $365.75 \pm 184.14 \mu \mathrm{s} / \mathrm{cm}$ was also in line with the WHO guideline.

Table 2. Comparison of the bacteriological quality of water Samples from springs, regular storage containers, covered buckets and covered buckets with taps in all communities in two weeks

\begin{tabular}{|c|c|c|c|c|c|c|c|c|c|}
\hline \multirow[t]{2}{*}{ Parameter } & \multicolumn{4}{|c|}{ Week 1} & \multicolumn{4}{|c|}{ Week 2} & \multirow[t]{2}{*}{ p value } \\
\hline & Spring & $\begin{array}{l}\text { Regular } \\
\text { storage } \\
\text { container }\end{array}$ & $\begin{array}{l}\text { Covered } \\
\text { buckets }\end{array}$ & $\begin{array}{c}\text { Covered } \\
\text { buckets } \\
\text { with taps }\end{array}$ & Spring & $\begin{array}{l}\text { regular } \\
\text { storage } \\
\text { container }\end{array}$ & $\begin{array}{l}\text { Covered } \\
\text { buckets }\end{array}$ & $\begin{array}{c}\text { Covered } \\
\text { buckets } \\
\text { with taps }\end{array}$ & \\
\hline Mean Total & $18.00 \pm$ & $14.00 \pm$ & $10.00 \pm$ & $10.00 \pm$ & $18.00 \pm$ & $12.77 \pm$ & $8.51 \pm$ & $8.51 \pm$ & $\mathrm{P}=0.21$ \\
\hline Coliform & 4.00 & 6.64 & 3.94 & 3.94 & 4.00 & 4.23 & 4.16 & 4.16 & \\
\hline Count $/ 100 \mathrm{ml}$ & & & & & & & & & \\
\hline Mean Total & 23750.00 & 14900.00 & $12247.00 \pm$ & 12247.00 & 23750.00 & $13350.00 \pm 1$ & $11112.00 \pm 8$ & $11112.00 \pm$ & $\mathrm{P}=0.12$ \\
\hline $\begin{array}{l}\text { Viable Count } \\
\text { of Water } \\
\text { (cfu/ml) }\end{array}$ & \pm 5678.9 & \pm 13546.5 & 8106.3 & \pm 8106.3 & \pm 5678 & 0988.7 & 424.7 & 8424.7 & \\
\hline Total Coliform & $18500 \pm 70$ & $8938.00 \pm$ & $7903.00 \pm 7$ & $7903.00 \pm$ & $18500 \pm 70$ & $9425 \pm 8924$ & $10244.00 \pm 7$ & $10244.00 \pm 7$ & $\mathrm{P}=0.02$ \\
\hline Count (cfu/ml) & 47.46 & 7247.52 & 561.51 & 7561.51 & 47.46 & 88 & 558.22 & 558.22 & \\
\hline
\end{tabular}

Table 2 compares the bacteriological quality of water samples from springs, regular storage containers, covered buckets and covered buckets with taps in all communities over 2 weeks.

The Total coliform count $/ 100 \mathrm{ml}$ of water samples from springs and regular storage containers in all communities in the first week had a mean of $18.00 \pm 4.00 / 100 \mathrm{ml}$ and $14.00 \pm 6.64 / 100 \mathrm{ml}$ respectively while water samples from the covered buckets introduced was $10.00 \pm 3.94 / 100 \mathrm{ml}$. The mean total viable count of 
water sample from springs and regular storage containers was $23750.00 \pm 5678.90 \mathrm{cfu} / \mathrm{ml}$ and $14900.00 \pm 13546.51 \mathrm{cfu} / \mathrm{ml}$ respectively while that of covered buckets was $12247.00 \pm 8106.34 \mathrm{cfu} / \mathrm{ml}$. The total coliform count of water sample from springs and regular storage containers was $18500 \pm 7047.46 \mathrm{cfu} / \mathrm{ml}$ and $8938.00 \pm 7247.52 \mathrm{cfu} / \mathrm{ml}$ respectively while samples from the covered buckets were 7903.00 \pm 7561.51 $\mathrm{cfu} / \mathrm{ml}$.

The Total coliform count $/ 100 \mathrm{ml}$ of water samples from springs and regular storage containers in all the communities in the second week was $18.00 \pm 4.00 / 100 \mathrm{ml}$ and $12.77 \pm 4.23 / 100 \mathrm{ml}$ while samples from covered buckets with taps containers was $8.51 \pm 4.16 / 100 \mathrm{ml}$. The total viable count of water samples from springs and regular storage containers had mean of $23750.00 \pm 5678.90 \mathrm{cfu} / \mathrm{ml}$ and $13350.00 \pm 10988.70 \mathrm{cfu} / \mathrm{ml}$ respectively while samples from covered buckets with taps containers was $11112.00 \pm 8424.72 \mathrm{cfu} / \mathrm{ml}$. The total coliform count of samples from springs and regular storage containers had a mean of $18500 \pm 7047.46$ $\mathrm{cfu} / \mathrm{ml}$ and $9425 \pm 8924.88 \mathrm{cfu} / \mathrm{ml}$ respectively while samples from covered buckets with taps had a mean total coliform count of $10244.00 \pm 7558.22 \mathrm{cfu} / \mathrm{ml}$. A statistically significant association was observed in comparing the mean Total Coliform Count of water samples from regular storage containers, covered buckets and covered buckets with taps. Two of the household regular storage container was found to contain Eschericia coli.

Table 3. Comparison of the Bacteriological quality of Water Samples from springs, Regular Storage Containers, Covered Kegs and Covered Kegs with Taps in All Communities over 2 weeks

\begin{tabular}{|c|c|c|c|c|c|c|c|c|c|}
\hline \multirow[t]{2}{*}{ Parameter } & \multicolumn{4}{|c|}{ Week 1} & \multicolumn{4}{|c|}{ Week 2} & \multirow[t]{2}{*}{ p value } \\
\hline & Springs & $\begin{array}{c}\text { Regular } \\
\text { storage } \\
\text { containers } \\
\end{array}$ & $\begin{array}{l}\text { Covered } \\
\text { buckets }\end{array}$ & $\begin{array}{c}\text { Covered } \\
\text { buckets } \\
\text { with taps }\end{array}$ & Spring & $\begin{array}{c}\text { Regular } \\
\text { storage } \\
\text { containers } \\
\end{array}$ & $\begin{array}{l}\text { Covered } \\
\text { buckets }\end{array}$ & $\begin{array}{c}\text { Covered } \\
\text { buckets } \\
\text { with taps }\end{array}$ & \\
\hline $\begin{array}{c}\text { Mean Total } \\
\text { Coliform Count } \\
\text { /100ml }\end{array}$ & $18.00 \pm 4$ & $12.25 \pm 4.8$ & $6.94 \pm 2.7$ & $6.94 \pm 2.7$ & $18.00 \pm 4.0$ & $11.92 \pm 4.3$ & $7.33 \pm 3.6$ & $7.33 \pm 3.6$ & $\mathrm{P}=0.34$ \\
\hline $\begin{array}{l}\text { Mean Total } \\
\text { Viable Count of } \\
\text { Water }(\mathrm{cfu} / \mathrm{ml})\end{array}$ & $\begin{array}{c}23750.00 \\
\pm 5678.9\end{array}$ & $\begin{array}{c}12271.00 \pm \\
8340.1\end{array}$ & $\begin{array}{c}10635.00 \\
\pm 7953.1\end{array}$ & $\begin{array}{c}10635.00 \pm \\
7953.1\end{array}$ & $\begin{array}{c}23750.00 \\
\pm 5678.9\end{array}$ & $\begin{array}{c}12463.00 \pm \\
6704.8\end{array}$ & $\begin{array}{l}112039.0 \\
0 \pm 8261.9\end{array}$ & $\begin{array}{c}112039.00 \\
\pm 8261.9\end{array}$ & $\mathrm{P}=0.00$ \\
\hline $\begin{array}{l}\text { Total Coliform } \\
\text { Count (cfu/ml) }\end{array}$ & $\begin{array}{l}18500 \pm \\
7047.46\end{array}$ & $\begin{array}{c}7708.00 \pm 8 \\
712.26\end{array}$ & $\begin{array}{c}8364.00 \pm \\
6944.41\end{array}$ & $\begin{array}{c}8364.00 \pm 6 \\
944.41\end{array}$ & $\begin{array}{c}18500 \pm 70 \\
47.46\end{array}$ & $\begin{array}{c}8371.00 \pm 6 \\
044.22\end{array}$ & $\begin{array}{c}8334.00 \pm \\
6695.24\end{array}$ & $\begin{array}{c}8334.00 \pm \\
6695.24\end{array}$ & $\mathrm{P}=0.02$ \\
\hline
\end{tabular}

Table 3 above highlights results of test of water samples from springs and regular storage containers as well as covered kegs with or without taps. In the first week, the mean total coliform count of $18.00 \pm 4.00 / 100 \mathrm{ml}$ and $12.25 \pm 4.88 / 100 \mathrm{ml}$ respectively were recorded for springs and regular storage containers while water samples from covered kegs had a mean of $6.94 \pm 2.76 / 100 \mathrm{ml}$.

Samples collected in the second week indicated that water samples from springs and regular storage containers in all the communities had a mean total coliform count of $18.00 \pm 4.00 / 100 \mathrm{ml}$ and $11.92 \pm 4.31 / 100 \mathrm{ml}$ respectively while samples from the covered kegs with taps had a mean of $7.33 \pm 3.69 / 100 \mathrm{ml}$. There was a statistically significant association between the means of Total Coliform Count of water samples from springs, regular storage containers, covered kegs and covered kegs with taps. A statistically significant association was also observed in comparing the mean Total Coliform Count of water samples from springs, regular storage containers, covered kegs and covered kegs with taps.

The $\mathrm{pH}$ of water is an important factor in its quality with wide fluctuations in optimum $\mathrm{pH}$ ranges leading to an increase or decrease in the toxicity of poisons in water bodies [7]. The mean $\mathrm{pH}$ values for the spring source had values lower than 6.5 recommended by the WHO. The acidic nature of the samples agrees with the assertion that the $\mathrm{pH}$ changes in water quality may be as a result of introduction of contaminants [5]. The generally low $\mathrm{pH}$ values obtained in the water samples might also be due to the high levels of free $\mathrm{CO}_{2}$, in the water samples, which may consequently affect the bacterial counts [4]. The mean electrical conductivity of springs and household regular storage containers were within the WHO guideline which is in conformity with another study in Nigeria [8]. The mean alkalinity for both springs and household regular storage containers were within the WHO guideline for drinking. Mean alkalinity of drinking water reflects the presence of bicarbonate ion which provides buffering action against acidic effects [9]. The mean chloride levels in the springs and regular storage containers were within the WHO permissible limit which implies that contamination was minimal. Presence of chloride may be an indication of pollution from sea water or

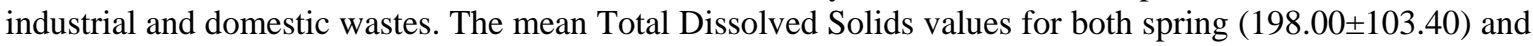
regular storage containers (196.00 \pm 107.27$)$ were also within the WHO permissible limit. A household water quality survey by researchers in Accomack and Northampton counties in Virginia revealed that average TDS concentrations were 275 and 291mg/l respectively for raw and tap water groups [10]. The mean total

IJPHS Vol. 3, No. 4, December 2014 : $253-258$ 


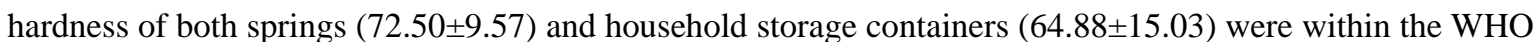
standard of drinking water and could be classified as moderately soft water. The concentration of trace metals in springs and household and regular storage containers was low for all the metal ions (Cadmium, Iron, Lead and Manganese). All the sources were safe from excessive concentration of all the trace metals since they were all below the WHO limit.

Water samples from the springs and water stored in household regular storage containers were of poor bacteriological quality. The total coliform count $/ 100 \mathrm{ml}$ in the spring water sample ranged from 12 to 20/100 ml while that of regular storage containers ranged from 6 to 20/100ml. None of the spring water samples satisfied WHO standard for drinking water quality while less than ten percent of the samples from the household storage container satisfied WHO standard of $<10 \mathrm{cfu} / 100 \mathrm{ml}$. This finding is in accordance with the finding in a similar study that majority of water supplies in Ibadan were contaminated and that contamination was higher at point of use [5]. The coliform count of spring water samples was significantly higher than that of samples from regular storage containers. This could be associated with method of water collection and storage. This finding agrees with a survey conducted in India which concluded method of collection of water as well as storage conditions affects the quality of water. ${ }^{11}$ The presence of coliform group of organisms in the water samples generally suggests that a certain selection of water may have been contaminated with faecal matter from either human or animal origin.

Our study looked at the coliform index which other studies have considered as an indicator of faecal pollution in water. The total and faecal coliforms have been used indicator of faecal contamination and as available testing technology [12]. The presence of coliform group and E.coli is due to faecal or environmental contamination and is an indication of the likely presence of other pathogenic bacteria like Salmonella spp, Shigella spp and Streptococcus spp which are capable of causing very serious diseases. A study conducted in Ibadan also noted that the greatest danger associated with drinking water is contamination by human faeces [14].

Eschericia coli was found in five percent of water samples from regular storage containers while none was found in the spring source water samples. This contamination could be as a result of participants dipping their hands inside water stored in their household storage containers during collection especially after using a toilet. This finding agrees with a similar study which found that dipping hand into water led to contamination [11].

Comparing spring water source with the different storage containers distributed to the participants, contamination was higher at the source and this agrees with one of the observational studies by other researchers that mean coliform levels were substantially higher in water sources than in household water storage containers [15]. Comparing water samples from covered buckets without taps and covered buckets with taps, contamination was significantly higher in samples from covered buckets without tap. It could also be as a result of method of collection. The type of media used in collecting water from the drinking water storage container might have been contaminated. Also, hands could be dipped into the containers during the process of collection. Researchers have observed that people generally took stored water from the [open] bucket by dipping thus resulting in contamination of otherwise safe water by their infected fingers [16]. Water samples drawn from the vessels with spigots were the least contaminated of all stored water samples in covered buckets, suggesting that water handling within the home was the major source of stored water contamination.

Comparing water samples from covered kegs without taps and covered kegs with taps, contamination was significantly higher in water samples from covered kegs with taps. This could be as a result of careless handling and unhygienic practices by the participants. A microbiological survey of water stored in Texas homes without municipal water connections found coliform bacteria significantly less often in storage vessels with openings less than $10 \mathrm{~cm}$ in diameter, from which water was typically poured, than in containers with wider openings, into which hands and dipping utensils could more easily be introduced [17]. The intervention vessels were generally preferred over other containers used in water storage in the homes. However, no feacal coliforms or E. coli was detected in stored water samples from households that used the intervention containers. The significant difference seen in contamination levels between households who dip and households that pour water out of the storage container could be attributed to the fact that serving utensils could not be placed through the opening of narrow-mouthed vessels.

The use of water vessels with narrow openings has previously been shown to improve water quality in the home, probably, by hindering the introduction of hands into the vessel [16],[18]. In addition to the narrow mouth and spigot, the special vessel had a screw-on lid, giving further benefits of hindering contamination in the treated drinking 


\section{CONCLUSION}

The study assessed the effect of different types of storage containers on drinking water quality in different communities in Ibadan. The study showed that drinking water sometimes gets contaminated during storage in household vessels, and that improvement in the design of household water storage vessels can reduce this risk. Safe water storage vessels alone cannot make water potable, but can help to preserve water quality after treatment. Therefore there should be an adequate training of participants on water storage, handling and treatment to ensure improvement in water quality. Interventions aimed at providing storage containers and treatment materials especially in the poor resource settings should be encouraged

\section{REFERENCES}

[1] Kulshreshtha, SN., “A Global Outlook for Water Resources to the Year 2025”, Water Resources Management, vol. 3, pp. 167-184, 2012.

[2] Federal Office of Statistics (FOS), "Digest of Statistics Federal Office of Statistics”, Lagos, 1995.

[3] World Health Organization, "Water for Health. WHO guidelines for drinking water quality", 2010. Accessed on $26^{\text {th }}$ June 2012 from http://www.worldwatercouncil.org/index.php?id=23

[4] Edema, MO, Omemu, AM., Fapetu, OM., "Microbiological and physicochemical analysis of different sources of drinking water”, Nigerian Journal of Microbiology, vol. 15, pp. 57-61, 2001.

[5] Oloruntoba, EO, Agbede OA., Sridhar, MKC., "Seasonal variation in physicochemical quality of Household drinking water in Ibadan, Nigeria”, An International Journal, Series B, vol/issue: 5(1), pp. 70-81, 2006.

[6] American Public Health Association, American Water Works Association and Water Environment Federation, "Standard Methods for the Examination of Water and Wastewater", American Public Health Association, Washington, D.C, 1998.

[7] Ali J., “An Assessment of the Water Quality of Ogunpa River Ibadan, Nigeria”, M.Sc. Dissertation, University of Ibadan, Nigeria, vol. 2, pp. 121, 1991.

[8] Onianwa, PC., Ogunniyi, OJ., Ogunnowo AA., "General Physico-chemical Quality of Drinking Water in Ibadan, Nigeria”, International Journal of Environmental Education and Information, vol/issue: 18(2), pp. 143-154, 1999.

[9] Sarapata, JS., “Bicarbonate Alkalinity in Drinking Water”, J. N. Engl. Water Works Assoc., vol. 108, pp. 277-287, 1994.

[10] Ross, BB., Allisonn, LS, Belote, JN., Diem, JF, Holden BE., Kellamm PL, Milbbourne, PM, Parrott, KR., Bourne AC., "Evaluation of Household Water Quality in Accomack and Northampton Counties, Virginia”, Virginia Cooperative Extension, Household Water Quality Series 46, Virginia Polytechnic Institute and State University Department of Biological Systems Engineering, 29, 2000.

[11] Tambekar DT., Banginwar YS., "Study on potential intervention for control of water borne diseases: promotion of storage, handling and serving practices of drinking water in hotels and restaurants”, Pollut. Res, vol. 24, pp. 371375, 2005.

[12] Wright J., Gundry S., R. Conroy, "Household drinking water in developing countries: a systematic review of microbiological contamination between source and point-of-use”, Tropical Medicine and International Health, vol/issue: 9(1), pp. 106-117, 2004.

[13] Talaro Kathleen, "Foundations in Microbiology", 4th edition, McGraw-Hills, New York, U.S.A, pp. 805, 2002.

[14] Apantaku, SO, Apantaku FS., Uzo Chukwu SA., "Nigeria Institute of Sciences and Technology", 22nd Proceedings, vol. 1, pp. 156- 157, 1998.

[15] Van Derslice J, Briscoe J., "All coliforms are not created equal: a comparison of the effects of water source and inhouse water contamination on infantile diarrheal disease”, Water Resources Res, vol. 29, pp. 1983-1995, 1993.

[16] Deb BC., Sirkar BK., Sengupta SP., "Intra-familial transmission of Vibrio cholerae biotype Eltor in Calcutta slums”, Indian Journal Medical Research, vol. 76, pp. 814-819, 1982.

[17] Koehler JE , Ries A., Tauxe R, “Cholera risk assessment in Texas 'Colonias,' El Paso County”, In: Program and abstracts of the 42nd Annual Epidemic Intelligence Service Conference; Atlanta, Ga. Abstract. 1991.

[18] Mintz ED, Reiff FM., Tauxe RV., "Safe water treatment and storage in the home: a practical new strategy to prevent water-bome disease”, Journal of the American Medical Association, vol. 273, pp. 948-953, 1995. 